\title{
Overview of the causes and management of drug shortages in the United States and in Hungary
}

\author{
BÉLA TURBUCZ ${ }^{1}$, BALÁZS HANKÓ ${ }^{1 *}$ \\ University Pharmacy Department of Pharmacy Administration, Semmelweis University Budapest, Hungary \\ *Corresponding author: Balázs Hankó \\ Email: hanko.balazs@pharma.semmelweis-univ.hu
}

Received: 22 October 2020 / Revised: 17 November 2020 / Accepted: 1 December 2020

\begin{abstract}
Drug shortages are a multifactorial international concern that are increasingly reported all over the world. A continuously rising number of cases could be observed since 2001 in the United States, but the issue is particularly significant since 2009. In Hungary, the same increasing tendency was observed; while in 2012464 shortages occurred, in 20201466 cases were reported. According to the US Food and Drug Administration, there are three root causes behind the shortages. This paper aims at conducting a comprehensive overview of literature, exploring these principal causes and additional factors deriving from them in detail and thereby explaining how each of these contributes to shortages. Furthermore, it will illustrate how the lack of sufficient information due to an imperfect warning system also exacerbates the issue. As the problem affects every stakeholder in the supply chain from patients to Marketing Authorisation Holders, each party should be involved in the development and implementation of mitigating strategies that can provide the basis of policy measures. The article highlights how international trends both in terms of affected therapeutic areas and causes of shortages are reflected in the Hungarian markets; therefore, similar approaches could be adapted to tackle the issue domestically and deliver enduring solutions.
\end{abstract}

Keywords: drug shortages, literature overview, causes and impacts of drug shortages, global tendencies, prevalence of shortages in Hungary

\section{Introduction}

During the second decade of the twenty-first-century people's mindsets have become increasingly global, with the need for immediate access to a variety of goods. However, the frequency and severity of medicine shortages in almost all member states of the European Economic Area (EEA) and in the United States (US) have substantially intensified only in the last couple of years. Some medicinal products are simply not available on a certain market even though there is sufficient economic power to pay them [1]. Drug shortages are a state when the available or calculated claim for medicines does not meet adequately at the end-user level. Causes are multiple and diverse among countries [2]. There are a complex set of factors underlying such shortages but various stakeholders of the supply chain of human medicine all agree that they mainly derive from the following root causes, according to Figure 1:

- Logistical [procurement of excipients] and regulatory challenges

- Maintaining mature Quality Management Systems

- Business and Economic Issues [3,4].

These factors can negatively affect patient recovery as delayed medicines and the use of re- placement treatments are more likely to cause medication errors. Drug shortages also have a detrimental impact on the finances and personnel management of health care sites [5]. As a result, physicians cannot manage their patient's therapy adequately or clinical pharmacists must provide an alternative treatment, which requires their substantial extra time and effort [6]. The issue of medicine shortages must be resolved as soon as possible, especially when "critical medicines" are affected [7]. The aim of this review is to develop a comprehensive overview of the problem with an emphasis on global occurrence [8]. Figure 2 shows the annual cases of new shortages identified through the last 2 decades in the US [9].

\section{Literature Review}

To gain a thorough understanding of the topic a search through Google Scholar and Pub Med was conducted between $19^{\text {th }}$ September 2020 and $12^{\text {th }}$ October 2020. The most frequent keywords and terms used included the followings: drug shortage as a global challenge, shortage impacts on stakeholders, causing factors of shortages, generics market, commonly affected products by shortages, handling of shortages, advanced protocols for shortages. Additional informa- 


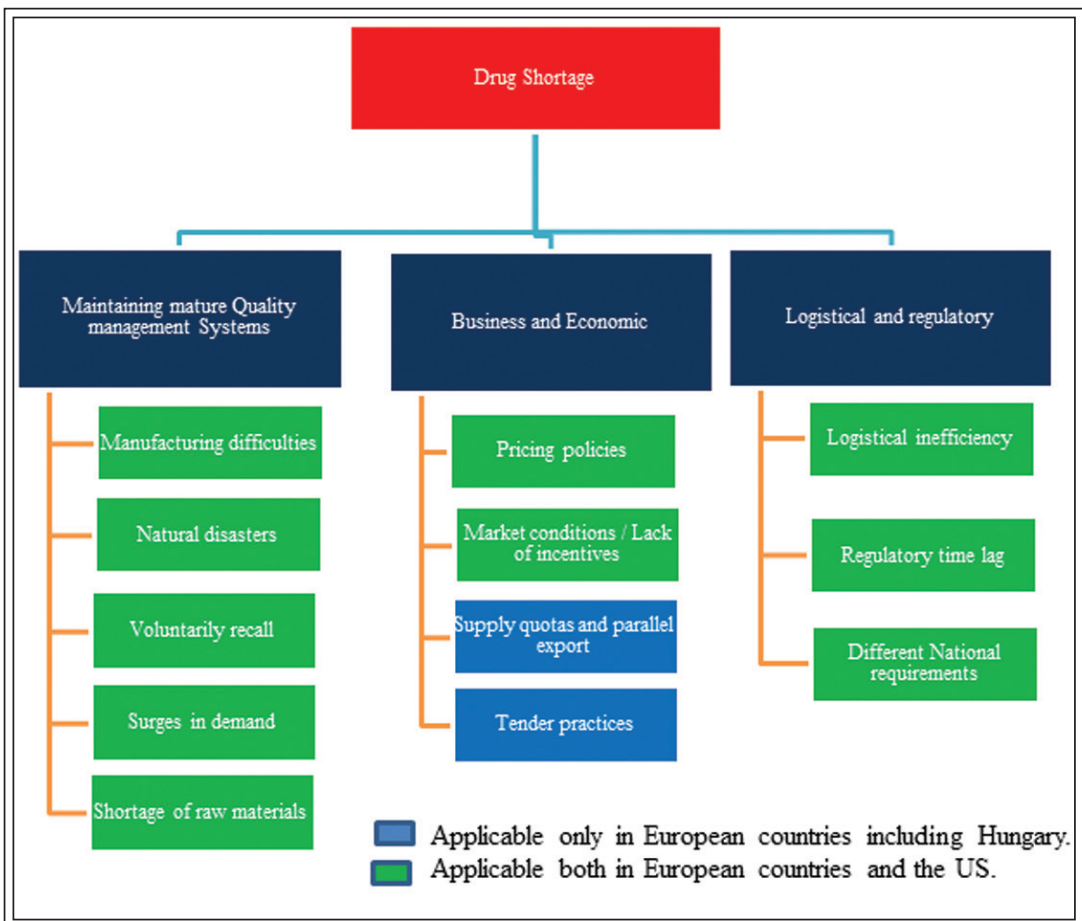

Figure 1 Potential root causes of shortages and derived factors [3,4].

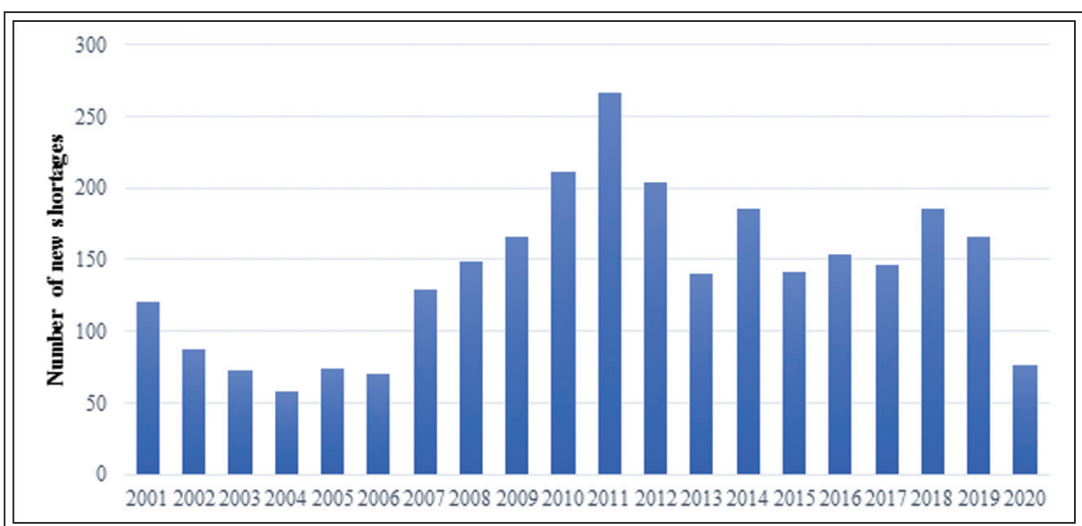

Figure 2 New shortages by year in the US between 2001-2020 [9]. ing annual new shortages in the United States between 2001 and 2020 and the therapeutic percentage of shortages between 2013 and 2019, the University of Utah information system and database was used.

Drug shortage is a state when the available or calculated claim for medicines does not meet demand adequately at the end-user level despite sufficient financial resources being available [1]. The problem has continuously been growing in the recent decades and the World Health Organization (WHO) reported more than 20 countries to be affected worldwide in 2011 [10]. Despite this being a global challenge, there is no single common definition to exactly determine the state of "drug shortage" [11]. Based on an Institute for Healthcare Informatics survey conducted in November 2011 in the US, there are five disease areas highly exposed to this problem, these being oncology, anti-infectives, cardiovascular, central nervous system, and pain management medications $[7,12]$. Unfortunately, drug shortages show an increasing trend based on the data of the ASHP reports from 2013 [13] and 2020 [9]. The same tendency can be observed in Hungary. In 2012, 464 reported shortages were reported [14], while the

tion has been collected from the American Society of Health-System Pharmacists (ASHP) website, the European Association of Hospital Pharmacist (EAHP) report and the National Institute of Pharmacy and Nutrition (OGYEI), and Food and Drug Administration (FDA) database. The following professional journals have also served as a source: The New England Journal of Medicine, The Lancet Oncology, The Oncologist, Mayo Clinic Proceedings, Journal of Parenteral and Enteral Nutrition, Journal of Oncology Practice, Journal of the American Medical Association, American Journal of Health-System Pharmacy: AJHP: official journal of the American Society of Health-System Pharmacists, American Journal of Pharmaceutical Education. To obtain relevant statistical data regard-
"List of Product Shortages" published by the National Institute of Pharmacy and Nutrition in 2020 contains 1466 products being short in supply [15]. This Hungarian data is based on MAHs legally obliged reports towards the Authority [16]. Lack of sufficient information due to an imperfect warning system contributes to the issue to a great extent [17]. According to US law, MAHs should notify the FDA in advance if they intend to discontinue supply [18], however nor administrative neither financial burdens are in prospect if they do so [17]. In case the notification does not happen, there is no chance to prepare healthcare systems for all direct and indirect consequences of drug shortages [19]. Manufacturers suggest that if they would be notified about the expected discontinua- 
tion of production of other MAHs, they would be able to increase production accordingly. However, this would require a much better flow of information among supply chain members [20].

According to the FDA, there are three root causes of shortages [3]. The first is business and economic issues. There are no incentives to market barely profitable drugs [21], resulting from strong price competition, the so-called "race to the bottom pricing" [22]. This can be traced back to basic economic principles, as companies rather invest their profit into drugs which promise a higher return [21] instead of old generics [23]. Another aspect of the first root cause is the highly concentrated generic market, [24] caused by the numerous mergers and acquisitions of companies since 1980 in the US [24]. As an example, the sterile injectable drugs for oncology are marketed only by three Marketing Authorization Holders (MAHs) [7]. Moreover, parallel distribution, a very controversial field which refers to business transactions between wholesalers registered in different markets, discussed in detail in section 2.1, can also potentially explain the first root cause. Tendering practice as "single winner approach" introduces the risk that the chosen company may not be able to supply the right quantity in the right time [4].

The second root cause according to FDA reports is the obligation to maintain the quality management as laid down in the Good Manufacturing Practice (GMP) [25]. To meet every standard, MAHs tend to remove batch for every suspected deviation from the GMP, which practice is referred to as voluntary recall [26]. From this root cause also derives to a more severe issue, manufacturing and quality problems, which were attributed to around $64 \%$ of shortages in 2017 [27]. This may primarily be due to subcontractors located on another continent, mostly in Asia [28]. To mitigate this issue, the FDA issued guidance on how to select proper subcontractors [29]. Another reason behind manufacturing bottlenecks can be that MAHs often use the same equipment to produce different drugs [20]. Furthermore, the shortage of raw materials can also often lead to inability to maintain the quality management, thereby resulting in shortages of medicine [3]. This is due to the reason that MAHs do not only depend on manufacturers, but also on suppliers located in great geographical distances, [30] mostly in China and India [31].

The third root cause [3] is logistical and regulatory challenges which are also in connection with outsourced activities [32]. What regards logistics, pharmacies and hospitals obtain medicines from wholesalers, and the highly restricted conditions of storing, selling and delivering drugs often cause delivery delays [33] "Just-in-time" stock management system also contributes short supply [34]. Despite occurring rarely, natural disasters or pandemics can cause large shortages if they destroy manufacturing capacity [3] or spike up demand [4]. If the level of demand raised over regular expectations, [37] MAH may not be able to keep up production capacity [38]. On the regulatory side, the decision to contract out any task results in high bureaucratic and administrative burdens towards different authorities which are becoming increasingly strict [39]. MAHs also report that the increasing regulatory control is generally detrimental to their ability to meet demand as planned [17].

Regardless of their cause, shortages have a grave impact on every stakeholder [5]. Often they can be managed using alternative medicinal products, [18,40], however, this may reduce patient safety due to various reasons, $[41,42]$ cause reputation damage for MAHs, hinder healthcare professionals from carrying out their tasks, [43] and increase labor cost $[44,45]$ because additional effort is needed to find the alternative therapy [46]. Besides, alternative medication often has a higher cost [45]. A prospective risk assessment plan is necessary to minimize all the above-mentioned impacts [8].

Healthcare institutions should be ready to mitigate the impact of shortages even before they occur. They should implement a shortage management strategy in advance, particularly to avoid the risk of making unethical triage decisions when already facing the shortage [18]. Healthcare institutions have to create and maintain an interdisciplinary expert committee who can make quick decisions, handle potential shortages, and minimize their impact [18]. A resource allocation committee should be delegated to monitor resources in the facility, [47] while if a specific therapeutic area is affected, an expert from that particular field should be involved [48]. The triage procedure must be adapted to shortages, and it should be based on patient characteristics after any conflict of interest has been excluded [49]. This also helps to avoid the necessity for professionals to make triage calls on their own when the amount of available medications is limited. Healthcare institutions should create formal guidelines in advance on how to identify and approve alternatives [50]. 
There are some complex cases when it is not possible to change the original agent [51]. It is in any case important to ensure through predefined procedures that priority is given to those who are younger or sicker $[48,49]$. The main goal is to not distinguish particular patients and always follow the principles of justice, beneficence, and nonmaleficence [52]. Drug shortage management starts when the first signal arrives from the market, which launches a chain reaction [17]. Operational assessment should be carried out, clarifying the expected duration of shortage and the available inventory, converting inventory count into common measurement units if necessary [18]. Furthermore, therapeutic assessment is needed to identify available alternative therapies and identify affected patient groups [49]. In Hungary, the most critical aspect is the communication between supply chain players [53]. Often pharmacists behind the counter need to improvise which may cause mistrust between them and the patients, resulting in professional reputation loss [18]. If a certain drug cannot be provided, the first step is checking replacement therapies on the Hungarian Competent Authority's website. If replacements are not available, the pharmacist notifies the prescriber to claim alternative therapy. The second step should be taken by wholesale distributors, who play an intermediary role between pharmacies and MAHs, and have the capability to identify and collect signals from the market which predict an approaching shortage [54]. They should apply for "contingent approval" and/ or "individual approval of OGYEI" that both grant an authorization to import from abroad [55]. Additionally, the physician has an alternative option to prescribe medicine non-registered in Hungary to avoid possible life-threatening consequences [56]. However, it is the MAHs' responsibility by law [57] to not only market medicinal products on a particular market but also prepare a shortage strategy in advance to mitigate potential impacts of a drug shortage. MAHs should also be responsible for accommodating unforeseen circumstances [17].

\subsection{Causing factors behind drug shortages}

Despite not being an explicit root cause, the lack of sufficient information due to an imperfect warning system contributes to the issue of drug shortages to a great extent [17]. In the US drug manufacturers must inform the Competent $\mathrm{Au}-$ thority (FDA) 6 months in advance in case they intend to stop the production of a certain medicinal product [18]. However, there is nor financial neither administrative fines for missing the report towards the FDA [58].The competent authority cannot mandate a MAH to produce a particular product. Without sufficient warning of upcoming discontinuation, there is no chance to prepare healthcare systems for all direct and indirect consequences of drug shortages [19]. Some MAHs do voluntarily alert the FDA about upcoming shortages. If all other MAHs would be notified in advance that a drug shortage is anticipated, they probably would be able to increase production to obviate it [17]. Wholesalers and other actors entitled to administer medicines for patients have also been inconsistent in providing information to health systems in relation to approaching drug shortages [2]. Drugs being short in supply are often only noted when patients walk into the pharmacy and try to purchase medicine, but it is no longer available. The pharmacist behind the counter should have reliable and timely information to manage patients therapy [59]. In case the particular medicinal product being in shortage is produced only by one MAH who would be the only source for wholesalers or hospitals, the situation is more severe [1].

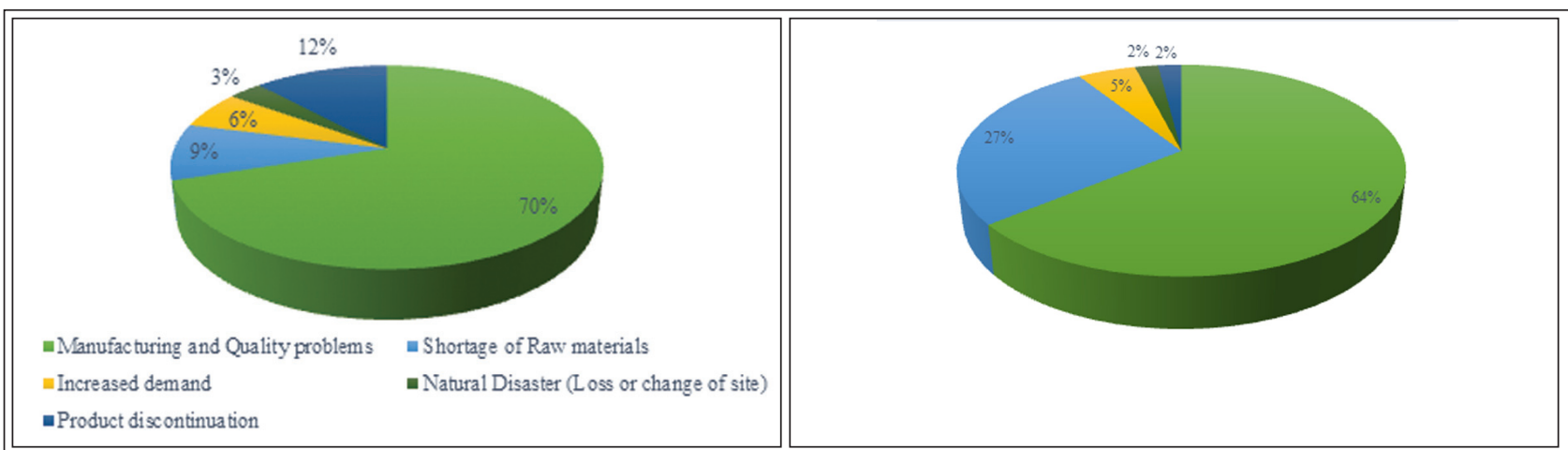

Figure 3 Causing factors behind the shortages (a: 2011-2013 [27], b: 2017 [62]) 
The statistics in Figure 3/a are based on the information of the MAHs reported towards the authority regarding the cause of occurred drug shortages. Table 1 reflects what is the proportion of different causes among all reported cases. Increased demand refers to a growth in the request for a particular product compared to its traditional amount of usage e.g.: COVID-19 [60]. The manufacturing and quality problems involve both delays due to capacity issues and voluntary recall due to bacterial contamination or any other foreign matter found in the current batch [61]. The analysis of the FDA data indicates that $6 \%$ of the shortages reported between January 1, 2011, and June 30, 2013, were due to increased demand and $3 \%$ because of natural disasters [27]. According to recent data (current as of 22-Oct-2019) by FDA (see Figure $3 \mathrm{~b}$ ) reports increased demand to account for $5 \%$ and natural disasters for $2 \%$, indicating little change in the proportion of these causes over the years [62]. On the other hand, the proportion of "manufacturing and quality problems" which decreased significantly (from $70 \%$ to $64 \%$ ), while product discontinuation causes were $12 \%$ of all shortages in 2017, compared to $2 \%$ in 20112013. Furthermore, the shortage of raw materials also shows a significant increase (from 9\% to 27\%) $[27,62]$.

\subsubsection{Root Cause 1 - Business and economic issues}

Lack of incentives to market barely profitable medicines

MAHs frequently remove less profitable products from their portfolio potentially causing short supply [21]. Causes of these decisions could be the poor profit, a new generic product arrives on the market, anticipated clinical demand, patent expiration, drug-approval status, increased regulatory requirements, the expense to correct manufacturing problems, or mergers [17]. If market conditions limit the profitability of MAHs they are undermotivated to continue the production of the given product and invest more money in improving its quality [4]. There is strong price competition in the pharmaceutical market, also referred to as " race to the bottom in pricing" [22]. This practice does not motivate MAHs to invest in the production of older generic drugs which have little potential returns [21]. The essential medicines are frequently generics, therefore relatively cheap to purchase, however, not easy to produce [23]. There is an open competition on the pharmaceutical market for generic medicines, which results in lower prices and reduces the return on investment of producers and marketers. As another economic factor, mergers and acquisitions of pharmaceutical companies since the 1980s often lead to decreased product quantity and lines or due to shifting production to another facility, further contributing to shortages [24]. Cost-containment actions such as reference pricing, payback mechanism or discounts, introduced by some countries to control public expenditures on pharmaceuticals also limit profitability and thereby the incentives of MAHs to produce certain medications. Such economic pressure on MAHs also motivates them to store lower quantities or extract from the market [4].

\section{Parallel distribution}

Occasionally, parallel distribution is also mentioned as a potential cause for medicine shortages, however, it is a highly controversial aspect. Parallel distribution refers to business transactions between wholesalers registered in different markets, which leverage the difference in prices among their countries [63]. This is made possible by the concept of a common EU market without domestic borders is embedded in articles $34-36$ of the Treaty on the Functioning of the EU. If manufacturers of a country produce the quantity necessary to meet the needs of their market, but a wholesaler exports a proportion of the products to a foreign market where they can gain a higher profit, a shortage will occur in the domestic market [64]. In response to this ethically questionable practice of wholesalers, MAHs introduced quotas to reduce the possible amount of exported products. Quotas control the amount of certain medicinal products available to countries to limit parallel trade. However, if quotas are not set at right levels to cover domestic demand, they can also contribute to drug shortages [38].

\section{Tendering practices}

Public tendering is used to increase price competition and thereby reduce purchase prices. In 2009, 18 EU member states used tendering practices for procuring medicinal products mostly for hospitals. In Hungary "Act CXLIII of 2015 on public procurement" regulates tender practices [65]. The single winner approach introduces the risk that the chosen company may not be able to supply the 
Table 1 Comparing root causes of shortages in EU/Hungary and the US [3,4].

\begin{tabular}{|c|c|c|c|}
\hline Root causes & $\begin{array}{l}\text { Derived shortage } \\
\text { factor }\end{array}$ & USA & EU including Hungary \\
\hline \multirow[t]{3}{*}{ Economic related } & $\begin{array}{l}\text { Market conditions } \\
\text { / Lack of incentives }\end{array}$ & \multicolumn{2}{|c|}{$\begin{array}{l}\text { Economic incentives favour highly profitable drugs, therefore MAHs } \\
\text { might discontinue the production of those with low profit margin. }\end{array}$} \\
\hline & Tender practices & Not applicable. & $\begin{array}{l}\text { Single winner structure leaves hospitals highly } \\
\text { dependent on one firm, who might not be able to } \\
\text { meet the whole demand. }\end{array}$ \\
\hline & $\begin{array}{l}\text { Supply quotas and } \\
\text { parallel export }\end{array}$ & Not applicable. & $\begin{array}{l}\text { Due to exporting to more profitable markets, } \\
\text { discrepancy arises between the volume } \\
\text { manufacturers release on a given market and the } \\
\text { ability of the wholesalers to satisfy patients' needs } \\
\text { from the said market. }\end{array}$ \\
\hline \multirow[t]{5}{*}{$\begin{array}{l}\text { Manufacturing } \\
\text { and quality }\end{array}$} & $\begin{array}{l}\text { Manufacturing } \\
\text { difficulties }\end{array}$ & \multicolumn{2}{|c|}{ Manufacturer cannot provide sufficient quantity or quality. } \\
\hline & Natural disasters & \multicolumn{2}{|c|}{$\begin{array}{l}\text { Production facilities have to discontinue production and/or have to } \\
\text { meet increased the demand for particular medicinal products which } \\
\text { would be essential to treat disaster victims. }\end{array}$} \\
\hline & Voluntarily recall & \multicolumn{2}{|c|}{$\begin{array}{l}\text { The supply of medicines could be significantly reduced because of } \\
\text { GMP issues. }\end{array}$} \\
\hline & Surges in demand & \multicolumn{2}{|c|}{$\begin{array}{l}\text { Due to unpredicted increases in the use of a particular product, supply } \\
\text { cannot meet the market needs e.g.: COVID-19. }\end{array}$} \\
\hline & $\begin{array}{l}\text { Shortage of raw } \\
\text { materials }\end{array}$ & \multicolumn{2}{|c|}{$\begin{array}{l}\text { Due to limited availability of ingredients production is forced to be } \\
\text { lower than normal manufacturing capacity e.g.: Valsartan case. }\end{array}$} \\
\hline \multirow[t]{3}{*}{$\begin{array}{l}\text { Logistical and } \\
\text { regulatory }\end{array}$} & $\begin{array}{c}\text { Logistical } \\
\text { inefficiency }\end{array}$ & \multicolumn{2}{|c|}{$\begin{array}{l}\text { Medicine would be available however patients are unable to acquire } \\
\text { due to various reasons. }\end{array}$} \\
\hline & $\begin{array}{c}\text { Regulatory time } \\
\text { lag }\end{array}$ & \multicolumn{2}{|c|}{ Medicine wait for MA renewal. } \\
\hline & $\begin{array}{l}\text { Different National } \\
\text { requirements }\end{array}$ & \multicolumn{2}{|c|}{$\begin{array}{l}\text { Specific requirements by authorities e.g.: specific label requirements, } \\
\text { pharmacovigilance system, and FMD regulation. }\end{array}$} \\
\hline
\end{tabular}

right quantity in the right time of the product, which is then sanctioned by fines. To mitigate this issue, when selecting the winner of the tender, besides the most important criteria, the price, the second alternative criteria should be the availability of the medicine. The single winner approach leaves hospitals highly dependent on one firm, which could be resolved by including second or third winners based on such multifactorial criteria, who could automatically supply if the first winner is unable to do so [4].

\subsubsection{Root Cause 2 - Maintaining mature quality management systems}

The pharmaceutical market does not acknowledge nor reward MAHs' effort of investing in quality management systems [3]. All MAHs have to meet regulatory requirements like the GMP which is set forth as a prerequisite of being permitted to operate on the pharmaceutical market. Mature quality systems conform to GMP principles and is based on performance and patient-focused approach, incorporating technology, statistical process control, and planning activities to make sure medicines are produced and supplied in a transparent manner [25].

\section{Voluntarily recall}

Recall refers to not marketing a specific batch of products because of a lack of confidence in safety or any other defect [26]. These recalls may have a fast and severe effect on the accessibility especially if certain drugs are marketed only by a few MAHs. A dilemma may arise if it is predicted that a voluntary recall will cause a drug shortage [66]. To resolve this dilemma, OGYEI may authorize the MAH to place particular batch onto the market to assure continuous supply even if it differs only formally from the marketing authorization guidelines but is otherwise safe to market. The procedure and the relating issues are described in $35 \S$ of Decree No. 52 of 18 November, 2005 of the Minister of Health [67]. 


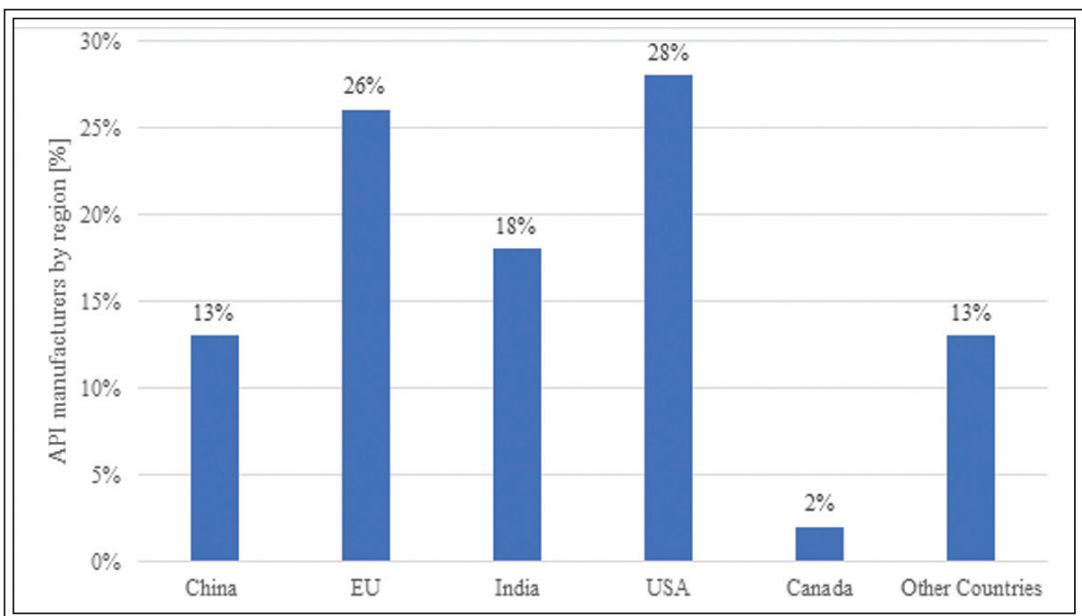

Figure 4 Global percentage of API manufacturers by region, Aug 2019 [31].

ed as one of the principal reasons behind medicine shortages [17]. Shortages of raw materials have a critical impact on the supply chain because even if multiple MAHs are producing the same medicinal product, they may have only one source of raw materials. Consequently, any interruption in the phase of procurement of raw materials can greatly affect the availability of the finished product [17]. This issue can also be tied back to the geographical concentration of production. Historically, the manufacturing of drugs for US citizens has

\section{Manufacturing difficulties}

According to FDA investigation, around $64 \%$ and $70 \%$ of shortages were attributed to manufacturing and quality problems. Pharmaceutical manufacturers often subcontract production to third parties in geographically distant locations to take advantage of significantly production costs of developing countries. Consequently, the physical manufacturing facility and company headquarters do not coincide [28]. Every party involved in the production process is responsible to work according to GMP, creating an additional responsibility for MAHs, who have to ensure that subcontractors also comply [29]. To ensure that these global guidelines are met, the new API regulation was introduced in 2013 in the EU. As a result, MAHs and regulatory authorities need to perform more personal audits over their contractors [68].

Bottlenecks can arise at various stages of the production process, for example, due to aged and inefficient equipment, the lack of competent workforce or resources shifted towards business areas with higher profit potential such as research and development. MAHs often use the same equipment to produce various products, therefore it is complicated to raise the level of production of one product without causing supply issues and delays for another [20].

\section{Shortage of raw materials}

On several occasions, disruptions in the supply chain of the raw materials bring forth shortages. The difficulties arising in the procurement of excipients and active substances has been highlight- been inland based [31], however, the import of raw materials particularly for active pharmaceutical ingredients (APIs) is continuously on the rise, making the stability of these channels essential for the whole supply chain [31] (Figure 4). As of August 2019 , only $28 \%$ of manufacturers procured Active Pharmaceutical Ingredients (APIs) as raw materials from domestic market, while the remaining $72 \%$ has been imported from overseas [31].

As materials are largely procured from non-European countries such as China or India, the stable drug supply of developed countries is highly dependent on these dominant producers [17].

In addition, there is a low number of suppliers capable of meeting quality standards required by EU or USA legislation, and many of them are affected by operative risks of countries with high occurrence of natural disasters, armed conflicts, or political instability. Problems also may arise due to, trade arguments, damage during transport, changing climate conditions, or a decreased yield of plants that are a source for materials [17].

\subsubsection{Root Cause 3 - Logistical and regulatory challenges}

Through the past decades, the pharmaceutical supply chain became higly complex and disintegrated as numerous industries have transmitted a higher portion of their production overseas [31]. Normally markets would respond to an upcoming shortage by raising production level, however logistical and regulatory burdens resulting from the overly complex supply chain often limits the ability and speed of MAHs in raising production. If MAHs want to modify production capacity they may have to obtain approvals from many different 
competent authorities and/or may have to find new API suppliers [4].

\section{Supply chain difficulties}

Most hospitals and pharmacies who are entitled to provide medicines for patients procure through wholesale distributors. Every procedure along the supply chain is highly regulated, therefore any small deviation from normal procedure may result in shortages. Post marketing surveillance and market approval requirements induce MAHs to only provide to those wholesalers who ensure strict compliance with their contract terms and procedures. Most MAHs and distributors use "just-in-time" stock management, which allows a lower amount of goods "on-hand". Benefits include optimized cashflow and storage capacity [34]. This inventory strategy is a widely-used practice among pharmaceutical companies, however, it results in higher exposure to unforeseen shortages. Delivery issues can also contribute to short supply, especially when too many pharmacies or hospitals in a certain region are using the same source as distributor [4].

\section{Natural disasters}

Natural disasters may reduce product availability drastically. Production or shipment capacity can be significantly cut back by fires, hurricanes, tornadoes, and floods. If a certain manufacturer is a sole-source of a product, a long-term shortage might occur because of the damage to manufacturing facilities. Sometimes disasters generate shortages as the treatment of victims creates an unexpected spike in the demand for certain medicines [5].

\section{Supply and demand issues}

Level of demand for a certain drug rises over general expectations due to a various reasons, such as a new indication being approved regarding the product, a disease being in high spread, or growing media attention around a product [5] MAHs are often simply not able to keep up with drastically increased demand and they are not able to exceed their capacity e.g.: COVID-19 [60].

\section{Regulatory Issues}

Another reason behind drug shortages can be the increasing control by the regulatory authorities. However, FDA regulatory bodies do not agree with this view as they identify manufacturing difficulties are the main causing factor [17]. Regulatory-related shortages are reported when FDA officers find non-compliance with GMP in the MAHs' facility or on their subcontractors' site [5]. Depending on the outcome of the inspection, the authority may seize involved products and schedule another inspection of the facility until the violation has been corrected. Further regulatory related issue if medicine that was previously approved on a certain market and its Marketing Authorization was invalidated, pending for MA approval or a medicine previously approved must wait for MA renewal so called "regulatory time lag" [4].

\subsection{Shortages as a global challenge}

Drug shortages became a global concern in the past decades both in Europe, and overseas (the USA and Canada). The World Health Organization confirmed that shortages occurred in more than 20 countries worldwide in 2011 [10]. It is complicated to classify and assess the issue because of the scarcity of publicly available data and different definitions between countries for drug shortage [11]. The Institute for Healthcare Informatics (IMS) in November 2011 identified five disease areas which are extremely exposed to drug shortages, meaning that $63 \%$ of all cases are reported in these categories. These areas were oncology, anti-

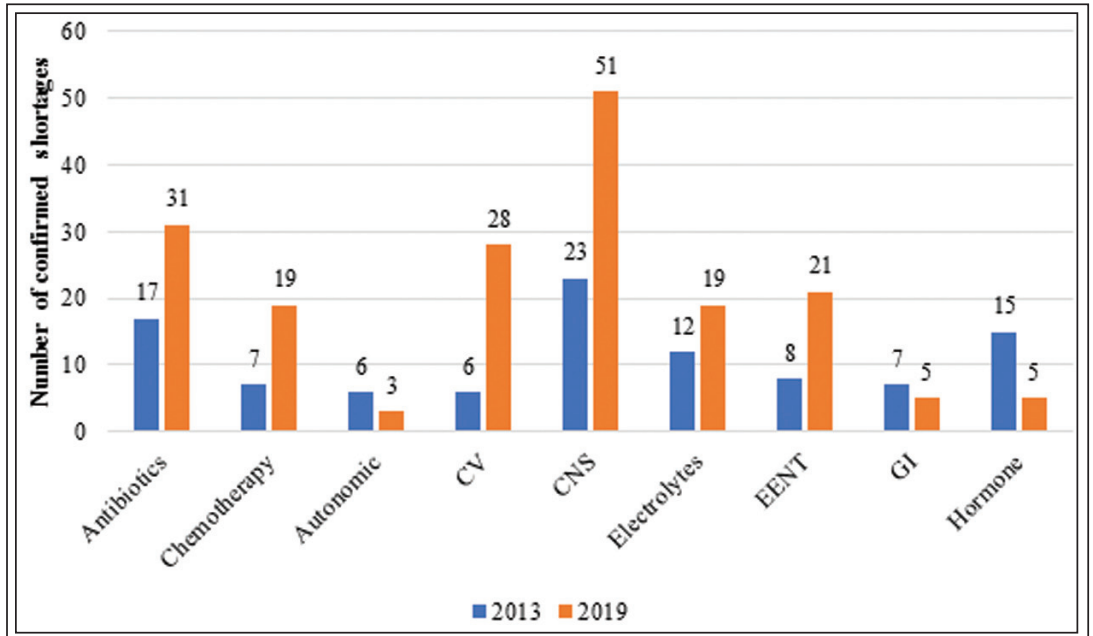

Figure 5 Affected drug classes with a shortage between 2013-2019 [9] [13]. CV: Cardiovascular, CNS: Central Nervous System, EENT: Eye, Ear, Nose and Throat, GI: Gastrointestinal 
Table 2 Reported causes of shortages by MAHs in Hungary from $13^{\text {th }}$ January 2020 till $20^{\text {th }}$ January 2020 [15]

\begin{tabular}{l|r|r}
\hline Commercial considerations & 922 & $63 \%$ \\
\hline Manufacturing problems & 395 & $27 \%$ \\
\hline Logistics and warehousing problems & 47 & $3 \%$ \\
\hline $\begin{array}{l}\text { Problems with the availability of } \\
\text { active substances }\end{array}$ & 43 & $3 \%$ \\
\hline Administrative problems & 34 & $2 \%$ \\
\hline Unexpected increase in demand & 21 & $1 \%$ \\
\hline Other reasons & 4 & $0 \%$ \\
\hline
\end{tabular}

infectives, cardiovascular, central nervous system and pain management, and generic injectables. The same five disease areas which are most often exposed to shortages have also been confirmed in 2013 [13] and in 2019 [9].

However, Figure 5 illustrates that some disease areas became more commonly affected between 2013-2019 with shortage for example chemotherapy products (from 7 to 19), cardiovascular products (from 6 to 28), central nervous system products (from 23 to 51) EENT products (from 8 to 21), electrolytes products (from 12 to 19). On the other hand, there are some disease areas with a lower occurrence of shortage in 2019, for example, autonomic products (from 6 to 3), gastrointestinal products (from 7 to 5), and hormones (from 15 to 5).

The same trend regarding the affected therapeutic classes was also observed in Hungary based on a research project conducted between $15^{\text {th }}$ of May and $30^{\text {th }}$ of June 2019 [69]. The survey was completed by 42 clinical pharmacists and highlighted the following groups: Blood and Blood-Forming Organs (52.4\%), Cardiovascular system (50\%), Antineoplastic agents (47.6\%), Antiinfectives for systematic use (38.1\%), and Nervous system (38.1\%) [69].

\subsubsection{Prevalence of shortages in Hungary}

The "List of Product Shortages" published by the National Institute of Pharmacy and Nutrition shows an increasing trend of shortages. In 2020, 1466 products were reported by the OGYEI [15], while in 2012 "only" 464 cases were listed [14]. The Hungarian pharmaceutical market usually reflects European trends, and this aspect is no exception. In Hungary, only those products make it to this list that have been reported by MAHs themselves as per their legal obligation: "In the event where a marketing authorization holder intends to temporarily suspend the distribution of a specific medicinal product in the territory of Hungary or wishes to discontinue the distribution of such medicinal product, the wholesalers of medicinal products engaged under contract and the government body for pharmaceuticals must be notified accordingly at the time of delivery of the last production batch to the medicinal product wholesaler, in any case at least two months before the scheduled suspension or termination of distribution, and shall be liable to provide a supply of the medicinal products in question until the date estimated for the suspension or termination of distribution in the quantity required to cover demand as estimated from previous turnover data. The government body for pharmaceuticals shall verify the availability of supplies notified by the marketing authorization holder in the quantity estimated to satisfy demand" [16]. The reporting process includes the filing of a specific Shortage Report Form on which the marketing MAHs are obliged to indicate not only the specific causes of the shortage but also the estimated period it will last for, and the methods by which the product could be substituted. Table 2 summarizes the causes of shortages as reported by the marketing authorization holders for the 1466 products on the list of January 19th, 2020.

The section of the Shortage Report Form on the specific causes of shortages can be individually edited on a case-by-case basis by MAHs. Based on this reporting system, it is possible to conclude that shortages in Hungary occur due to the above listed 6 reasons among which commercial considerations and manufacturing problems account for $90 \%$ of all the shortages.

\subsection{Impact of drug shortages and strategies to mitigate them}

Regardless of the original cause of a drug shortage, it has a grave impact on every stakeholder in the supply chain [17]. Shortages would severely affect the effectiveness of patient therapy and could simoultaneosly hinder healthcare professionals from doing their jobs effectively. It would force them to take on additional work, as the working hours spent mitigating the effect of shortages has already tripled between 2004 and 2010. A shortage is always associated with a higher level of risk due to the discontinuation of regular care and using alternative substitution that are less safe and cause a higher occurrence of medication errors [5]. This is because physicians can be forced to prescribe an alternative drug they may not be familiar with [43]. When working with unfamiliar 
substances health care professionals may miscalculate the dosage, thereby increasing the occurrence of overdosing or underdosing. Moreover, when patients are "triaged", the medicines for which there is no known alternative substitute are preserved for those who are suggested to have the best medical prognosis, thereby reducig the quality of care some patients receive [17] .

To mitigate such severe impacts, drug shortage management has to start when the first piece of information arrives pertains to approaching interruption. The appearance of a potential drug shortage launches a "chain reaction" from procurement until final therapeutic decision making. The drug shortage team has to measure the expected operational and therapeutic impacts on patient care to develop a final action plan for its approval and implementation [5]. A designated person should be responsible to perform the operational assessment, which should cover all details of approaching shortage like estimate available stock on hand, and the availability of an alternative supplier or alternative therapy [70]. In practice, this is usually the responsibility of the chief hospital pharmacist.

The designated person in charge of drug shortages management can contact the MAHs responsible for marketing affected products, distributors, FDA, the Centers for Disease Control and Prevention (CDC), and other sources to identify the cause of the interruption and its expected duration. In case the shortage has not already been reported by MAHs and made available on the FDA and ASHP shortage websites as well, the appointed person ahould report the supply interruption. These reports for example when the product will be available again meaning great help to hospitals and persons how entitled to provide medicines for patients to develop strategies [18].

After the fact of shortage has been confirmed, the clinical pharmacist officer has to assess "onhand stock" and estimate the period it can last for. Pharmacy Department has to assess available stock and analyze based on past usage proportions whether the inventory stock can last to cover demand during the expected short supply period.

The Therapeutic Assessment can be adjusted by the same appointed person who conducted the Operational Assessment. The main target to identify alternative therapies and to assess the affected patient groups [18].

In case a drug is critically low in stock and existing alternatives for certain patient groups are highly undesirable, it may be required to prioritize the dispense of the drug for these patient groups. Prioritization criteria can be based on the medicationuse evaluation data upon prescribing and administration trends. Further criteria can be the characteristic of therapeutic application (curative vs. palliative). Triage practice for such scenarios should be developed in advance by an interdisciplinary team and follow strict ethical considerations [49].

Available therapeutic alternatives should be procured and stockpiled in advance under the management of the Pharmacy Department, who has to ensure sufficient supplies to meet all patient needs.

\section{Conclusions}

The most crucial point of maintaining a strictly regulated pharmaceutical supply chain is protecting patient safety by legally assuring that both the highest quality and sufficient quantity of medicines will be available to satisfy patients' needs. Drug shortages may compromise this ambition, while they can also reduce the effectiveness of the healthcare system in general, thereby causing further risks for patient safety from multiple aspects. Even though drug shortages may arise due to different causes, the consequences in the supply chain are almost identical despite the initial trigger. As root causes and associated factors underlying the shortages are well-described in literature, this should be an easily avertable issue. Nevertheless, shortages remain a global problem, as a continuously rising number of cases were observed over the last decades both internationally and in Hungary. The most affected therapeutic areas being critical medications, drug shortages should be considered a current health crisis, and therefore a comprehensive solution must be adopted in the coming years to tackle this phenomenon. Firstly, a comprehensive and effective reporting system should be adopted to ensure every stakeholder is notified about the shortage in time. Almost all European member states obligate stakeholders to notify a specific institution according to Directive 2001/83/EC Article 81 and 23a of the European Parliament and of the Council of 6 November 2001 on the Community code relating to medicinal products for human use [57]. Table 3 demonstrates that how many kind of reporting systems exist at the same time in European territory. Even though they have the common aim of obtaining the same information, they have been created based on different logics and they operate in different ways, therefore they are not comparable to each other. 
Table 3 Comparing reporting systems in Europe [1,71,72]

\begin{tabular}{|c|c|c|c|}
\hline Country & Reportable products & $\begin{array}{l}\text { Frequency } \\
\text { of database } \\
\text { updating }\end{array}$ & Short description \\
\hline Austria & Unlimited & Weekly & $\begin{array}{l}\text { The voluntary list provided by } \\
\text { MAHs regarding their products. }\end{array}$ \\
\hline Belgium & $\begin{array}{l}\text { If unavailability poses a } \\
\text { risk to public health/ no } \\
\text { therapeutic alternative } \\
\text { available }\end{array}$ & Daily & $\begin{array}{l}\text { MAHs have to report by } \\
\text { law any shortage that will last for } 2 \text { weeks. }\end{array}$ \\
\hline Croatia & Only reimbursed products & Monthly & A list is available for download at website. \\
\hline England & $\begin{array}{l}\text { Products for community } \\
\text { pharmacy only }\end{array}$ & Monthly & Pharmacists via direct email. \\
\hline Estonia & Unlimited & On-call basis & It changes with new information every day. \\
\hline France & $\begin{array}{l}\text { If unavailability poses a } \\
\text { risk to public health/ no } \\
\text { therapeutic alternative } \\
\text { available }\end{array}$ & Daily & Pharmacists and hospitals \\
\hline Germany & $\begin{array}{l}\text { If unavailability poses a } \\
\text { risk to public health/no } \\
\text { therapeutic alternative } \\
\text { available }\end{array}$ & $\begin{array}{l}\text { In cases } \\
\text { assumed to } \\
\text { be of special } \\
\text { interest to } \\
\text { healthcare } \\
\text { professionals }\end{array}$ & $\begin{array}{l}\text { MAHs should report to different institutions. } \\
\text { List is often not up to date, and not all shortages } \\
\text { are listed here because it is not mandatory. }\end{array}$ \\
\hline Hungary & Unlimited & Weekly & $\begin{array}{l}\text { Based on MAHs information } \\
\text { also have a national website where they propose } \\
\text { a solution for substitutions. }\end{array}$ \\
\hline Italy & Unlimited & Weekly & $\begin{array}{l}\text { MAHs, health care providers, health } \\
\text { departments, patients, or associations. }\end{array}$ \\
\hline Latvia & Unlimited & Daily & $\begin{array}{l}\text { Anyone (hospital, pharmacy, patient) could use } \\
\text { this website to report. }\end{array}$ \\
\hline Norway & Unlimited & Weekly & $\begin{array}{l}\text { Both Norwegian Authority and the national } \\
\text { centre of shortage of drugs in hospital has } \\
\text { webpages open to everyone. }\end{array}$ \\
\hline Poland & Unlimited & $\begin{array}{l}\text { At least } \\
\text { bimonthly }\end{array}$ & $\begin{array}{l}\text { Chef Pharmaceutical Inspectorate collects data } \\
\text { from the pharmacist who are obliged to report } \\
\text { online by giving details of nature of shortage. }\end{array}$ \\
\hline Spain & Unlimited & On-call basis & $\begin{array}{l}\text { MAHs or health authorities of autonomous } \\
\text { communities. }\end{array}$ \\
\hline Netherlands & Unlimited & Daily & MAHs, wholesalers, pharmacists. \\
\hline
\end{tabular}

Secondly, transparent and effective communication would be favourable not only from MAHs towards the Authority but also among other stakeholders in the supply chain. New communication platforms should be created, which can provide an appropriate information gathering system while also protecting business interests and the integrity of the supply chain. Moreover, healthcare institutions should designate a person or team responsible for developing and implementing an agile strategy to prevent and mitigate the effect of drug shortages. Finally, if communication issues have been resolved among stakeholders, special inventory measures can be taken to protect scarce resources and ensure the disposal of medicines in the most reasonable manner. In conclusion, the drug shortage problem demands a quick and enduring solution to avoid unnecessary burden on patients, extra workload of health care professionals, and to reduce to use of expensive alternatives.

\section{Future perspectives and possible solutions}

The impact of drug shortages is still not fully identified. Future studies should move from characterizing the problem towards developing a solution to reduce or even eliminate the occurrence and so impacts of drug shortages. It would be a 
great step ahead if we could assess shortages based on the severity of their impact on patients. It would be cost-effective to measure such impact severity using the same method in all member states at the same time [73].

On the regulatory side, a "Supportive Attitude Practice" from the competent authority would be a great step to avoid post-approval changes hindering the availability of a product. For example, different pack sizes at the national level based on Marketing Authorization and multi-country packages should be accepted in case of a confirmed shortage of a medicine.

From an economic perspective, incentives would be necessary to ensure that life-saving drugs remain on the market even when sufficient profits are no longer achievable. Reasonable market conditions including foreseeable pricing, payback and reimbursement mechanism would provide help to keep MAHs on a particular market or willing to enter the market. Concentration of markets should also be avoided, as in case more than one MAHs supply a product there is lower chance for a shortage to occur.

To mitigate manufacturing and quality-related issues, policymakers should reward MAHs who are investing in manufacturing reliability and quality, as this ensures the supply medicines continuously for patients.

Finally, to improve communication channels, MAHs have to communicate with competent authorities when anticipating or experiencing a shortage to speed up the transmission of relevant information to all stakeholders, and thereby allow for the preparation of impact mitigation strategies as soon as possible.

\section{References}

1. Bochenek T, Abilova V, Alkan A, Asanin B, Beriain I de $\mathrm{M}$, Besovic Z, et al. Systemic measures and legislative and organizational frameworks aimed at preventing or mitigating drug shortages in 28 European and Western Asian Countries. Front Pharmacol. 2018;8. https://doi.org/10.3389/fphar.2017.00942

2. Birgli AG on behalf of EAEPC. An Evaluation of Medicines Shortages in Europe with more in-depth review of these in France, Greece, Poland, Spain and the United Kingdom. 2013. [Internet] [cited 19 September 2020]. Available from: https://www.eaepc. org/images/pdf/evaluation.pdf

3. FDA. Drug Shortages: Root Causes and Potential Solutions A Report by the Drug Shortages Task Force. 2019. [Internet] [cited 22 September 2020]. Available from: https://www.fda.gov/media/131130/download

4. Joint stakeholder paper. Addressing the root causes of medicines shortages Supply chain Stakeholders' views on root causes and solutions. 2019. [Internet] [cited 22 September 2020]. Available from: https:// www.efpia.eu/media/413378/addressing-the-rootcauses-of-medicines-shortages-final-051219.pdf

5. Fox ER, Birt A, James KB, Kokko H, Salverson S, Soflin DL, et al. ASHP guidelines on managing drug product shortages in hospitals and health systems. Vol. 66, American Journal of Health-System Pharmacy. 2009. p. 1399-406. https://doi.org/10.2146/ ajhp090026

6. Woodend AK, Poston J, Weir K. Drug shortages - Risk or reality? Can Pharm J. 2005;138(1):27-30. https://doi. org/10.1310/hpj5105-370

7. Fox ER, SweetB V.,Jensen V.Drug shortages: A complex health care crisis. Mayo Clin Proc. 2014;89(3):361-73. https://doi.org/10.1016/j.mayocp.2013.11.014

8. Acosta A, Vanegas EP, Rovira J, Godman B, Bochenek T. Medicine Shortages: Gaps Between Countries and Global Perspectives. Front Pharmacol. 2019; 10:1-21. https://doi.org/10.3389/fphar.2019.00763

9. American Society of Health-System Pharmacists. Drug Shortages Statistics National Drug Shortages: New Shortages by Year 2020. [Internet] [cited 18 September 2020]. Available from: https://www.ashp. org/Drug-Shortages/Shortage-Resources/DrugShortages-Statistics?loginreturnUrl=SSOCheckOnly

10. Gray A, Manasse R H. Shortages of medicines: a complex global challenge. Bulletin of the World Health Organization 2012;90:158-158A. https://doi. org/10.2471/BLT.11.101303

11. De Weerdt E, Simoens S, Casteels M, Huys I. Toward a European definition for a drug shortage: A qualitative study. Front Pharmacol. 2015; 6:1-9. https://doi. org/10.3389/fphar.2015.00253

12. IMS Institute for Healthcare Informatics. Drug shortages: a closer look at products, suppliers and volume volatility. [Internet] [cited 25 September 2020]. Available from: http://eyeonfda.com/wpcontent/uploads/2011/11/IMS-IHI-Drug-ShortagesReport-Final.pdf

13. Kearson ML. Drug Shortages : the good, the bad and the ugly Common Drug Classes in Short Supply Drug Shortages: Top Five Classes. The Florida Society of Health-System Pharmacists (FSHP). 2018. [Internet] [cited 27 September 2020]. Available from: https://cdn.ymaws.com/www.fshp.org/resource/ resmgr/2018_annual_meeting/speaker_handouts/ kearson.pdf

14. Csakurdáné dr. Harmathy Zs., [A GYEMSZIOGYI szerepe a gyógyszerhiány megelőzésében és kezelésében a 2012. év tapasztalatai [Internet] [cited 25 September 2020] Available from: https://www.ogyei. gov.hu/dynamic/Gyogyszereink_2012_6_small.pdf

15. Országos Gyógyszerészeti és Élelmezés-egészségügyi Intézet. OGYEI Összes termékhiány [Internet] [cited 13 January 2020]. Available from: https://ogyei.gov. hu/gyogyszeradatbazis/.

16. Act XCV of 2005 on Medicinal Products for Human Use and on the. 2020 p. 1-76.

17. Lee Ventola C. The drug shortage crisis in the United States causes, impact, and management strategies. 
P T. 2011;36(11):740-57. [Internet] [cited 05 October 2020]. Available from: https://www.ncbi.nlm.nih. gov/pmc/articles/PMC3278171/

18. Fox ER, McLaughlin MM. ASHP guidelines on managing drug product shortages. Am J Heal Pharm [Internet]. 2018 1;75(21):1742-50. https://doi. org/10.2146/ajhp180441

19. Patel SM. Causes, Impact and Management of Drug Shortage Crisis. Dep Pharm Pract Mercer Univ Coll Pharmacy, Atlanta, Georg. 2015;1(1):1-3. [Internet] [cited 02 October 2020]. Available from: https://smjournals.com/pharmacology/fulltext/ smjpt-v1-1002.php

20. Jensen V, Lorene M Kimzey MJG. FDA's role in responding to drug shortages. Am J Heal Syst Pharm 2002; 59:1423-5. https://doi.org/10.1093/ ajhp/59.15.1423

21. Schweitzer SO. How the US Food and Drug Administration can solve the prescription drug shortageproblem.AmJPublicHealth.2013;103(5):e104. https://doi.org/10.2105/AJPH.2013.301239

22. Deroo, Christian "Pay-To-Play: The Impact Of Group Purchasing Organizations On Drug Shortages," American University Business Law Review, Vol. 3, No. 1 (2018). [Internet] [cited 02 October 2020]. Available from: https://papers.ssrn.com/sol3/papers. cfm?abstract id $=3155955$

23. Gatesman ML, Smith TJ. The shortage of essential chemotherapy drugs in the United States. N Engl J Med. 2011; 365(18):1653-5. https://doi.org/10.1056/ NEJMp1109772

24. Danzon P, Epstein A, Nicholson S. Mergers and Acquisitions in the Pharmaceutical and Biotech Industries. Manag Decis Econ. 2007; 1; 28:307-28. https://doi.org/10.2139/ssrn.468301

25. Patel K, Chotai N. Documentation and Records: Harmonized GMP Requirements. J Young Pharm. 2011; 3(2):138-50. https://doi.org/10.4103/09751483.80303

26. Nagaich U, Sadhna D. Drug recall: An incubus for pharmaceutical companies and most serious drug recall of history. Int J Pharm Investig. 2015;5(1):13-9. 1 https://doi.org/10.4103/2230-973X.147222

27. DRUG SHORTAGES: Public Health Threat Continues, Despite Efforts to Help Ensure Product Availability GAO-14-194: Published: 2014. [Internet] [cited 18 September 2020]. Available from: https://www.gao. gov/products/GAO-14-194

28. Murray P. Third-Party Manufacturing From Concept to Contract Pharm Outsourcing. 2020;1-8. [Internet] [cited 27 September 2020]. Available from: https://wWw.pharmoutsourcing.com/FeaturedArticles/166240-Third-Party-Manufacturing-FromConcept-to-Contract/

29. Food and Drug Administration. Guidance for Industry. Contract Manufacturing Arrangements for Drugs: Quality Agreements. 2016; [Internet] [cited 27 September 2020]. Available from: https://www.fda. gov/regulatory-information/search-fda-guidancedocuments/contract-manufacturing-arrangementsdrugs-quality-agreements-guidance-industry
30. Bignami F, Mattsson P, Hoekman J. The importance of geographical distance to different types of $R \& D$ collaboration in the pharmaceutical industry. Ind Innov. 2019 14; 27:1-25. https://doi.org/10.1080/13662 716.2018 .1561361

31. Woodcock J. Safeguarding Pharmaceutical Supply Chains in a Global Economy. US Food Drug Adm. 2019;1-13. [Internet] [cited 12 October 2020]. Available from: https://www. fda.gov/news-events/congressional-testimony/ safeguarding-pharmaceutical-supply-chains-globaleconomy-10302019

32. Cheong M. Logistics Outsourcing and 3PL Challenges. 2003 Dec 14; [Internet] [cited 16 October 2020]. Available from: https://www.researchgate. net/publication/37595239_Logistics_Outsourcing_ and_3PL_Challenges

33. Draksiene G. Good drug distribution practice and its implementation in drug distribution companies. Medicina (Kaunas). 2002;38(5):488-90. [Internet] [cited 04 October 2020] Available from: https:// pubmed.ncbi.nlm.nih.gov/12474678/

34. Moosivand A, Rajabzadeh Ghatari A, Rasekh HR. Supply Chain Challenges in Pharmaceutical Manufacturing Companies: Using Qualitative System Dynamics Methodology. Iran J Pharm Res IJPR. 2019;18(2):1103-16. https://doi.org/10.22037/ ijpr.2019.2389

35. Wiske C, Ogbechie O, Schulman K. Options to Promote Competitive Generics Markets in the United States. J Am Med Assoc. 2015; 29; 314:1-2. https://doi. org/10.1001/jama.2015.13498

36. Fox ER, Birt A, James KB, Kokko H, Salverson S, Soflin DL, et al. ASHP guidelines on managing drug product shortages in hospitals and health systems. Am J Heal Pharm. 2009;66(15):1399-406. [Internet] [cited 04 October 2020] Available from: https://www. ashp.org/-/media/assets/policy-guidelines/docs/ guidelines/managing-drug-product-shortages.ashx https://doi.org/10.2146/ajhp090026

37. Lateef F. Patient expectations and the paradigm shift of care in emergency medicine. J Emerg Trauma Shock. 2011 Apr;4(2):163-7. https://doi.org/10.4103/09742700.82199

38. Bogaert P, Bochenek T, Prokop A, Pilc A. A qualitative approach to a better understanding of the problems underlying drug shortages, as viewed from Belgian, French and the European Union's perspectives. PLoS One. 2015;10(5):1-20. https://doi.org/10.1371/journal. pone.0125691. https://doi.org/10.1371/journal. pone.0125691

39. Handoo S, Arora V, Khera D, Nandi PK, Sahu SK. A comprehensive study on regulatory requirements for development and filing of generic drugs globally. Int J Pharm Investig. 2012; 2(3):99-105. https://doi. org/10.4103/2230-973X.104392

40. Musazzi UM, Di Giorgio D, Minghetti P. New regulatory strategies to manage medicines shortages in Europe. Int J Pharm. 2020; 579:119171. https://doi. org/10.1016/j.ijpharm.2020.119171

41. Miljković N, Godman B, Kovačević M, Polidori P, 
Tzimis L, Hoppe-Tichy T, et al. Prospective Risk Assessment of Medicine Shortages in Europe and Israel: Findings and Implications. Front Pharmacol. 2020; 11:357. https://doi.org/10.3389/fphar.2020.00357

42. Char DS, Magnus D. Ethics of Disclosure Regarding Drug Shortages That Affect Patient Care. Vol. 121, Anesthesia and analgesia. United States; 2015. p. 2623. https://doi.org/10.1213/ANE.0000000000000798

43. Kaakeh R, Sweet B V., Reilly C, Bush C, DeLoach S, Higgins B, et al. Impact of drug shortages on U.S. health systems. Am J Heal Pharm. 2011;68(19):18119. https://doi.org/10.2146/ajhp110210

44. De Weerdt E, De Rijdt T, Simoens S, Casteels M, Huys I. Time spent by Belgian hospital pharmacists on supply disruptions and drug shortages: An exploratory study. PLoS One. 2017;12(3):1-15. https:// doi.org/10.1371/journal.pone.0174556

45. Barlas S. Severe drug shortages impose heavy costs on hospital pharmacies: senate bill might help ... or not. P T. 2011

36(5):242-302. [Internet] [cited 08 October 2020] Available from: https://www.ncbi.nlm.nih.gov/pmc/articles/ PMC3138364/

46. Fink S. International efforts spotlight traditional, complementary, and alternative medicine. Am J Public Health. 2002; 92(11):1734-9. https://doi. org/10.2105/AJPH.92.11.1734

47. Kong HE, Grant-Kels JM, Stoff BK. Applying the ethical principles of resource allocation to drugs in limited supply during a public health crisis. Vol. 83, Journal of the American Academy of Dermatology. 2020. p. 170-1. https://doi.org/10.1016/j.jaad.2020.04.078

48. Valgus J, Singer EA, Berry SR, Rathmell WK. Ethical challenges: managing oncology drug shortages. J Oncol Pract. 2013; 9(2): e21-3. https://doi.org/10.1200/ JOP.2012.000779

49. Flynn J, Chubbs K, Gladney-Martin S, Singleton R, Pullman D. Triage in times of drug shortage. Healthc Manag forum. 2015; 28(5):202-5. https://doi. org/10.1177/0840470415588677

50. Clark SL, Levasseur-Franklin K, Pajoumand M, Barra M, Armahizer M, Patel D V, et al. Collaborative Management Strategies for Drug Shortages in Neurocritical Care. Neurocrit Care. 2020; 32(1):22637. https://doi.org/10.1007/s12028-019-00730-7

51. Gomez Y, Adams E, Hoogmartens J. Analysis of purity in 19 drug product tablets containing clopidogrel: 18 copies versus the original brand. J Pharm Biomed Anal. 2004; 34(2):341-8. https://doi.org/10.1016/S07317085(03)00533-8

52. Jahn WT. The 4 basic ethical principles that apply to forensic activities are respect for autonomy, beneficence, nonmaleficence, and justice. J Chiropr Med. 2011; 10(3):225-6. https://doi.org/10.1016/j. jcm.2011.08.004

53. ESZK KKGYT Gyógyszerhiányok kezelésére vonatkozó gyakorlati ajánlások. [Internet] [cited 12 October 2020]. Available from: https://www.mgytkgysz.hu/docman/altalanos-informa ciok/224-eszkkkgytt-gyogyszer hianyok-kezelesere-vonatkozogyakorlati-ajanlasok/file
54. Costantino RC.TheU.S. medicinechest:Understanding the U.S. pharmaceutical supply chain and the role of the pharmacist. J Am Pharm Assoc (2003). 2020; https://doi.org/10.1016/j.japh.2020.07.018

55. 44/2004 of the Minister for Health, Labour Affairs and Family on the prescription and dispensing of medicinal products for human use. 2020 p. 1-30.

56. Government Regulation 448/2017. On authorisation of the prescription and individual use of medicinal products for human use. Paragraph 5(1). 2020 p. 1-8.

57. European Parliament, Council. Directive 2001/83/EC of the European Parliament and of the Council on the Community code relating to medicinal products for human use 2001/83/Ec.

58. McKenna M. Hospital pharmacists scrambling, amid vast drug shortages: emergency physicians between roc and a hard place. Vol. 57, Annals of emergency medicine. United States; 2011. p. A13-5. https://doi. org/10.1016/j.annemergmed.2010.12.006

59. Barber N, Smith F, Anderson S. Improving quality of health care: the role of pharmacists. Qual Health Care. 1994; 3(3):153-8. https://doi.org/10.1136/qshc.3.3.153

60. Fox ER, Stolbach AI, Mazer-Amirshahi M. The Landscape of Prescription Drug Shortages During the COVID-19 Pandemic. J Med Toxicol Off J Am Coll Med Toxicol. 2020; 16(3):311-3. https://doi. org/10.1007/s13181-020-00786-4

61. Haleem RM, Salem MY, Fatahallah FA, Abdelfattah LE. Quality in the pharmaceutical industry - A literature review.SaudiPharm JSPJOffPublSaudiPharmSoc. 2015; 23(5):463-9. https://doi.org/10.1016/j.jsps.2013.11.004

62. U. S . Drug Shortages: Root Causes and Recent Statistics. 2020. [Internet] [cited 12 October 2020]. Available from: https://www.drugs.com/drugshortages/stats

63. Melck B. Parallel Exports Lead to Drug Shortage Problems in the Heart of Europe. IHS Healthc Pharma Blog. 2012;1-5. [Internet] [cited 12 October 2020]. Available from: http://healthcare.blogs.ihs. com/2012/10/09/parallel-exports-lead-to-drugshortage-problems-in-the-heart-of-europe/

64. Zaprutko T, Kopciuch D, Bronisz M, Michalak M, Kus K, Nowakowska E. Drug shortages as a result of parallel export in Poland - Pharmacists' opinions. Health Policy (New York). 2020; 124:563-7. https:// doi.org/10.1016/j.healthpol.2020.03.003

65. CXLIII of 2015 on public procurement (as in force on 8 August 2018) This document has been produced for informational purposes only. 2018;(August):1-164.

66. Onakpoya IJ, Heneghan CJ, Aronson JK. Postmarketing withdrawal of 462 medicinal products because of adverse drug reactions: A systematic review of the world literature. BMC Med.2016;14(1):111. https://doi.org/10.1186/s12916-016-0553-2

67. Allowed differences from the Marketing Authorisation (formal forma defect). 2020;(1):8869. [Internet] [cited 18 October 2020].Available from: https://ogyei.gov. hu/formal_defect

68. European Union. Active pharmaceutical ingredients into the European Union. 2013; [Internet] [cited 12 October 2020]. Available from: https://ec.europa. 
eu/health//sites/health/files/files/documents/active_ pharmaceutical_ingredients_leaflet_en.pdf

69. Vida R, Sebok S, Nyaka B, Hornyák J Botz L. Survey of drug shortages in Hungarian hospitals. Eur J Hosp Pharm. 2020;27(Suppl 1):53-4. [Internet] [cited 12 October 2020] Available from: https://ejhp.bmj.com/ content/27/Suppl_1/A18.2

70. Health Products Regulatory Authority. Medicinal Product Shortages, A framework for a multistakeholder approach to handling shortages of human medicinal products. 2018. [Internet] [cited 12 October 2020] Available from: https://www.hpra. ie/docs/default-source/publications-forms/guidancedocuments/adv-g0020-medicines-shortagesframework-v2.pdf?sfvrsn=4
71. European Association of Hospital Pharmacists (EAHP). MEDICINES SHORTAGES IN EUROPEAN HOSPITALS, 2018. Available from: [Internet] [cited 12 October 2020] Available from: http://www. medicinesshortages.eu/

72. Pauwels K, Huys I, Casteels M, Simoens S. Drug shortages in European countries: A trade-off between market attractiveness and cost containment? BMC Health Serv Res. 2014;14(1). https://doi. org/10.1186/1472-6963-14-438

73. Tucker EL, Cao Y, Fox ER, Sweet B V. The Drug Shortage Era: A Scoping Review of the Literature 2001-2019. Clin Pharmacol Ther. 2020; https:// doi.org/10.1002/cpt.1934. https://doi.org/10.1002/ cpt.1934 